\title{
Fight for the Poor: Grassroots NGOs and Educational Assistance in China
}

\author{
Xinyu Wang \\ Xuzhou N.O.1 Middle School, Quanshan, Xuzhou, China
}

\begin{abstract}
Local grassroots non-governmental organizations (NGOs) contribute to local governance in rural China. They are independent civil organizations and represent the power of common people who are aware of charity work. However, we know little about their functioning mechanics and existing problems about Chinese grassroots NGOs. This research focuses on local grassroots NGOs' impact and effectiveness, examining Ganlin as a case (i.e. a local educational assistance organization in rural China). Through surveys and interviews, this paper evaluates the development of local NGOs in rural China. The findings show that grassroots NGOs in China lack talent, professionalism, and public participation. These problems result in a significant gap between the actions of grassroots NGOs and the real impacts on poor students. This paper provides practical methods related to each problem for NGOs to function better. In addition, it sheds light on future NGOs' development in rural China and other developing countries.
\end{abstract}

Keywords: grassroots NGO, educational assistance, the structure of organizations, local politics in China.

\section{Introduction}

Poverty alleviation is of great importance to building a prosperous society for all countries. China has been devoted to poverty alleviation for decades. The goal of the Communist Party of China is to eliminate absolute poverty by the current standard (570 dollars family income in 2020) by the end of 2020. For a long time, many components of society have contributed to this difficult task, including governments, businesses, and non-governmental organizations (NGOs). NGOs have played an important role in accumulating public efforts and raising public awareness to focus on problems that are hard to solve by governments.

In the wake of the popularity of the term NGO dating back to the late 18th century in western countries, many people devote themselves to this field. In the year 1994, the China Charity Federation was founded in Beijing, representing that China's charity work was on track. People acted to raise money and offer free help to the people in need or when disaster happened. With governmental help, NGOs have sprung up continuously after 2000 and people paid more attention to this new type of organization from then on. By the end of 2010, there were 440,000 social organizations registered in civil departments. 


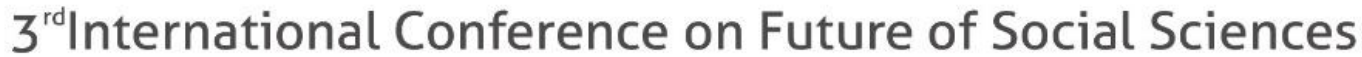

Figure Error! No text of specified style in document.-1: The Number of NGOs in China.

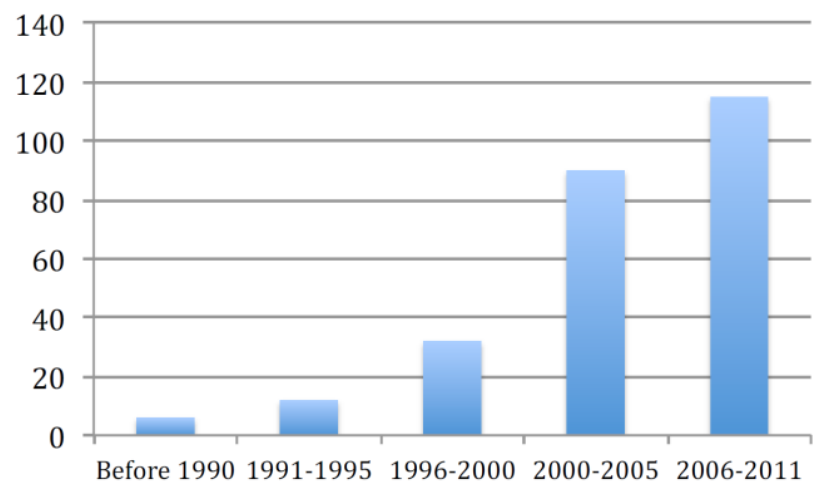

According to Figure 1, since 2000, NGOs have developed rapidly in China. 2008 is the most important year mainly because the Wenchuan Earthquake measuring 8.0 on the Richter scale occurred in Sichuan on the 12th of May. It caused a total of 69,227 deaths and was the most destructive earthquake since 1949. People from all over the country donated relief supplies and volunteered at the frontline. They realized the importance of charity work, which promotes the development of social organizations and charity careers. Moreover, as of November 2008, the nation's donated funds were 65.25 billion CNY. However, no reports showed any details about the budget and expenditure due to the limitation of technology and lack of management. From then on, NGOs realized that they should cooperate with governments in order to become more effective. Due to these reasons, 2008 is commonly called the First year of Public Welfare. From 2010, researchers began to use organizational analysis to state NGO's impacts. Then, in 2011, there are several scandals such as donation frauds so that governors and researchers began to rethink charity. The National People's Congress promulgated the People's Republic of China Charity Law in 2016 to standardize the order.

Existing research on NGOs can be divided into two categories. The first type focuses on philanthropy in one country about history, background, management, and many other aspects. The second type is comparing charity work between or among countries and learn from each other. However, current studies about grassroots NGOs are limited, and most researchers utilize broad theories or definitions to describe the general situation. There are only data on the number of new NGO to illustrate the development of NGOs, but not details about the micro-scale management within the NGO. Therefore, this study provides a nuanced examination of local grassroots NGOs in China and offers more management suggestions to help them do a better job.

In China, the definitions of NGOs are vague and there exist many different typologies. In this research, I focus on local, small-sized NGOs with charity features. There are several reasons for this concentration. First, grassroots NGOs are very different from government-lead or national organizations. They have unique characteristics, such as offering low-income families deep care, and donating all available resources to rural areas. Second, since grassroots NGOs are in the private sector, they face many functioning and credibility problems. Many founders are not able to strengthen their organization. Nevertheless, we need 


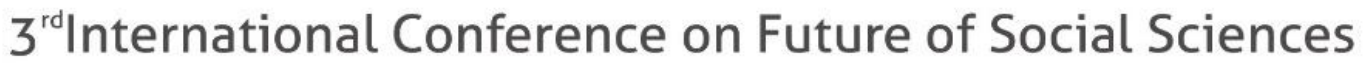

to find out common problems with management and provide suggestions for grassroots NGOs in developing countries.

Therefore, this research examines how grassroots non-profit organizations help and affect poor children's lives in rural China. I argue there are three main problems in Chinese grassroots NGOs - the lack of talents, professionalism and participation. Therefore, the evidence shows that there is a negative relationship between NGO's effort and its real impact. In this paper, I examine a case of a local grassroots educational NGO named Ganlin in Jiangsu province. I have conducted surveys among volunteers and students, interviews with the founder and active volunteers, fieldwork to show grassroots NGOs' current situation. The main finding is that grassroots NGOs in developing countries like China do help solve some social problems, though they have trouble improving themselves in charity work and organization structure.

In this paper, the first section provides an overview of the current literature on grassroots NGOs in China. They overstate the national organizations and fail to take into account the private organizations. The second section provides a basic introduction to NGOs in China. Also, it states the argument that grassroots organization lack talent, lack professionalism and have low public participation. The third section discusses grassroots NGOs' function mechanics and current problems. The case study, Ganlin Educational Assistance Organization, demonstrates the relationship between organizations' actions and the impacts on poor children. Unraveling the common problems is significant to the development of charity work in China and other developing countries. The fourth section presents the empirical findings from surveys and interviews. The last section offers practical suggestions to solve these problems and paves the way for further research.

\section{Literature Review}

As widely known, NGOs are developed well in developed countries, but in developing countries, they do poorly on managing the organizations. The definitions and rules in the charity field are so vague that different researchers have their own definitions. Also, most existing studies focus on critics on NGOs, using evidence to support their argument. Nevertheless, they are lack of detailed solutions that are easy to understand for grassroots organizations. Further, effort was made to review the existing literature which focuses on grassroots NGOs in developing countries. I generally categorize them into two types.

The first type is focused on vertical comparison: philanthropy in a single country, mainly digging into NGOs' history and development, pointing out some of the management nowadays. In her work, Jing Chen, presents a case study of a grassroots NGO and argues that grassroots play an important role in helping poor students. Although she points out the lack of attention paid to these organizations, she states how government should react to help grassroots organizations instead of solving the problems within the organizations. Wei Liu indicates that it is important to find out the relationship between Chinese culture and charity work. His paper is limited and the experiences do not have universality in developing countries. Also, Liu's suggestions are given to national and large-scale NGOs. Philip 


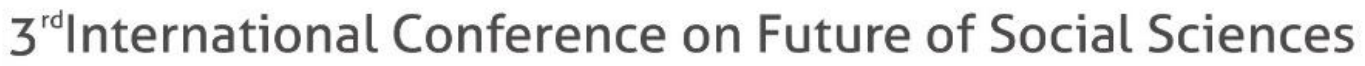

H.Brown and Albert Park use designed Math models, data collection and survey to argue that poverty affects both educational investments and learning significantly. However, quantitative methods just show the current situation. All in all, this type of study highlights too much about one country's specific social and cultural conditions that can influence the development of NGOs.

The second type is cross-country studies, comparing charity work in one country to that in another and improving the situation (horizontal comparison). In Changzhen Li's paper, families are significant in taking care of children and states are the last to provide help, which is called the social assistance paradigm. This study uses western countries' paradigms to solve problems in China. Hongbo Li did research on the U.S. public charities' marketing and drew on lessons to promote China's public charity marketing. These studies emphasize too much on the differences between countries. Most studies overemphasize strong organizations but neglect the local ones. When giving advice, they imply that countries should take actions but neglect NGOs' high status in solving their own problems.

\section{Argument}

With the economic development, due to the unfair distribution mechanism in China, remote location, and imperfect social security system, there are many poor populations in rural China. By promoting the poverty alleviation policy, the incidence of rural poverty in China has dropped from $97.5 \%$ in 1978 to $1.2 \%$ at the end of 2018 . The rate of poverty reduction is significantly greater than the global rate in the same period. Grassroots NGOs go to the poor and contribute a lot during the whole process.

In the early 1980s, there were no independent NGOs, but people gathered together to promote social equality. In the 1990s, the charity organizations were small and everyone who worked for them knew each other. Entering the $21^{\text {st }}$ century, with the rising awareness of the charity, volunteers, who devote themselves to charity work, gathered together and started their voluntary group. When a group expands and more volunteers participate, it can be registered in local or provincial Civil Affairs Bureau. In the recent ten years, the total number of social organizations nationwide is 81600 , increasing at a rate of $7.1 \%$ compared to 2017 . As of December $31^{\text {st }}, 2018$, the number of charitable organizations registered by the civil affairs departments has reached 5,285 nationwide. While the term "NGO" is widely used, there are also many other over-lapping terms used such as nonprofit, voluntary, and civil society organizations. In many cases, the use of different terms does not reflect descriptive or analytical rigor, but is instead a consequence of the different cultures and histories in which thinking about NGOs has emerged. The fast growth of NGOs presents growing social awareness in developing countries.

In this research, through qualitative analysis and data collection, I argue that grassroots NGOs have problems, though they did contribute to alleviating poverty. They are lack of talents so that the organizational department and individual tasks are not clear to volunteers. Moreover, they are lack professionalism and do not have many online tools or platforms. Low public participation makes the organization hard to expand influence. Winston Churchill 


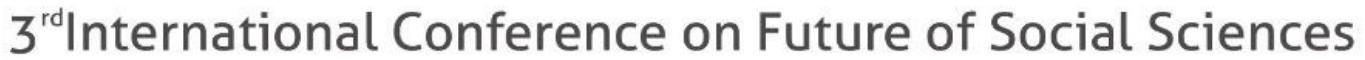

once said, "We make a living by what we get, but we make a life by what we give." Social grassroots NGOs have a common aim, and this research intends to provide them with practical advice to solve their problems.

\section{Methods}

\subsection{Case selection}

In this research, Ganlin Educational Assistant Organization is selected as a case because of its impact and charity process-

First, Ganlin is a representative charity power in Xuzhou, Jiangsu Province. It was founded in 2014 by five ordinary people aged around fifty. In April 2017, it was registered in Yunlong District Civil Affairs Bureau as a non-governmental social organization. The main aim of this NGO is to provide rural kids with care and financial support in their education. By 2020, Ganlin has over 600 volunteers distributed in the five districts of Xuzhou and other cities.

Second, Ganlin has three donation programs and contains different processes like other grassroots. More specifically, donators can visit the children, participate in festival activities, and donate online. They donate 30 dollars every month to one assigned child, and all the money will go to the child's family bank account directly. Volunteers need to do tasks calling the children once a week, participating class meeting - to care about the students. In addition, they also raise funds from cooperative companies.

\subsection{Fieldwork and Interviews}

Fieldwork and interviews with volunteers are adopted in this study to investigate and locate potential problems in this organization. I engaged in the donation process myself and paid visits to five families in two districts in Xuzhou. A local volunteer knew well about each child and their family's condition. The children we visited all live in wooden houses and poor environment. Most of the families have sick grandparents and more than two children. There are only one or two laborers in a big family. The illiteracy rate has declined steadily over the years, reflecting the success of 9-year compulsory education and the high primary school enrollment rate. However, there are still huge gaps between resources in rural and urban areas. Nevertheless, the parents do their utmost to let their children go to school. After receiving Ganlin's donations, it is easier to have access to school.

In the whole process, I interviewed one of the founders (Interviewee A) and one core volunteer (Interviewee B) in Ganlin face to face. Information collected from the one-hour interview reflects grassroots' advantages as well as the many difficulties they are facing. Ganlin does well in giving long-term care to low-income families and supporting the students' study. They recorded all the children's personalities and growing track. Volunteers not only introduce the children to the donator, but also keep focusing on the children's recent condition. In the interviews, they could easily talk about a kid they have helped for four years and how they persuade him to go back to school. Moreover, they are expert at finding job resources for low-income families to ensure they can make a living by themselves with the 


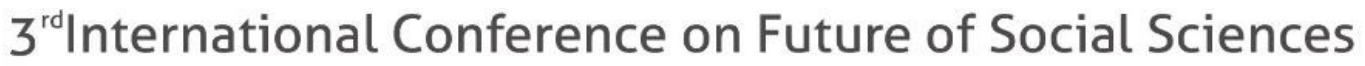

donation.

On the development of Ganlin, interviewee A told me that they do not have any full-time staff because all the money is used for children. They do not want to use their resources for functioning but to help low-income families. Although there are over 500 volunteers nominally, only 30 volunteers use most of their free time working for this organization. Interviewee A also states that she does not intend Ganlin to expand its scale because their time is limited. Ganlin focuses more on providing substantive help to children but neglecting their own function mechanics.

On the donations, Ganlin raises five to seven dollars every month in recent years. However, one of the core members implies that Ganlin is not qualified to raise money publicly. Grassroots NGOs can rarely meet the strict requirements for public charity fundraising. In fact, by the end of 2018, there were 1,925 foundations (20\%) with public fundraising qualifications across the country because the requirements are strict. Therefore, core volunteers have had a conversation with Xuzhou Charity Federation and Civil Affairs and they reached an agreement to this special way of donation, which is through WeChat, which is one of the most popular multiple-purpose messaging and social medias in China. Then, interviewees are asked whether there is a platform for Ganlin to report the donations to the public. The founder states that neither the government nor Xuzhou Charity Federation has a website or official account for social charity organizations to put announcement. Also, all of Ganlin's volunteers are mid-aged people and are not able to build their own technology platform. Nevertheless, she promised that all the money would be directly given to the students and they also gives the donators remittance as feedback.

\subsection{Data Collection}

According to 2019 National Economic and Social Development Statistical Bulletin, 11.09 million rural poor people were lifted out of poverty in 2019 , and more than 10 million people were reduced from poverty for 7 consecutive years. However, national reports cannot accurately reflect reality. Ganlin's database only contains poor children's personal information and their family background. Though volunteers know each family's situation, they have never conducted any surveys to learn children's responses to help.

To learn the students' current condition and responses to Ganlin's help, I prepared twelve questions and printed out 110 surveys in total. Printed questionnaires are more convenient for children to fill in because not every family has smartphones and their parents may work away. Also, children in rural areas are more relaxed when writing on a piece of paper. I mailed the questionnaires to four schools in different districts both within and around the city, Xuzhou. Mailing to schools can guarantee the response rate and improve efficiency because children have access to the questionnaires easily. Eventually, 104 surveys have been sent back and the response rate is $94.5 \%$.

Another survey is designed for the main volunteers working for Ganlin. I designed an online survey containing 14 questions and circulated the survey in a WeChat group, which gathered volunteers; the response rate is $92 \%$. 


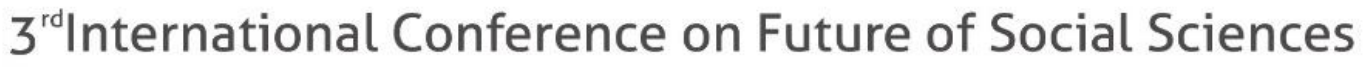

\subsection{Results and Findings}

Figure Error! No text of specified style in document.-2: Children's Willingness to Volunteer by Ganlin's Influence

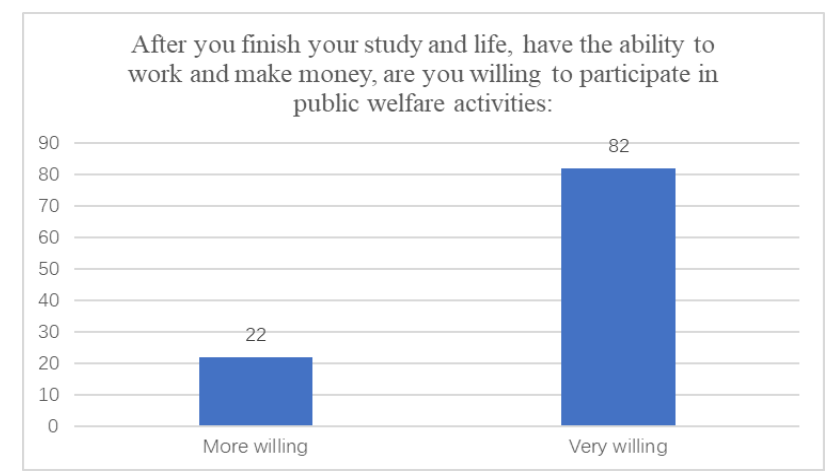

Figure Error! No text of specified style in document.-3: Children's Response on Ganlin's Donations

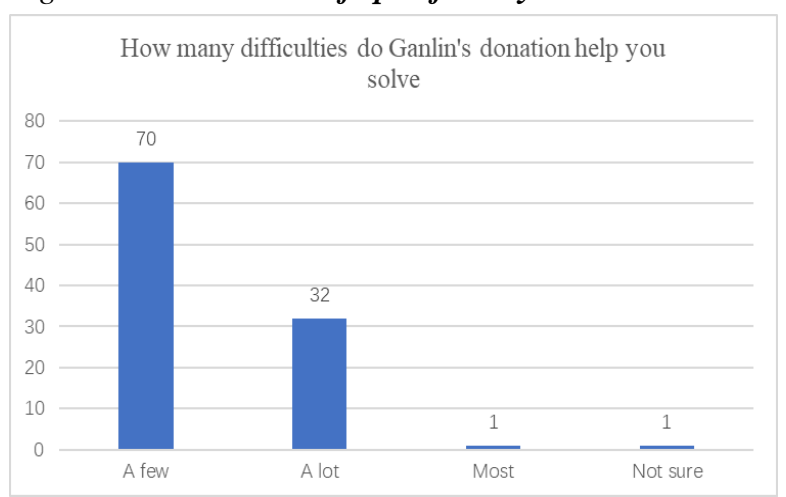

Figure Error! No text of specified style in document.-4: Volunteers' Thoughts on Donations

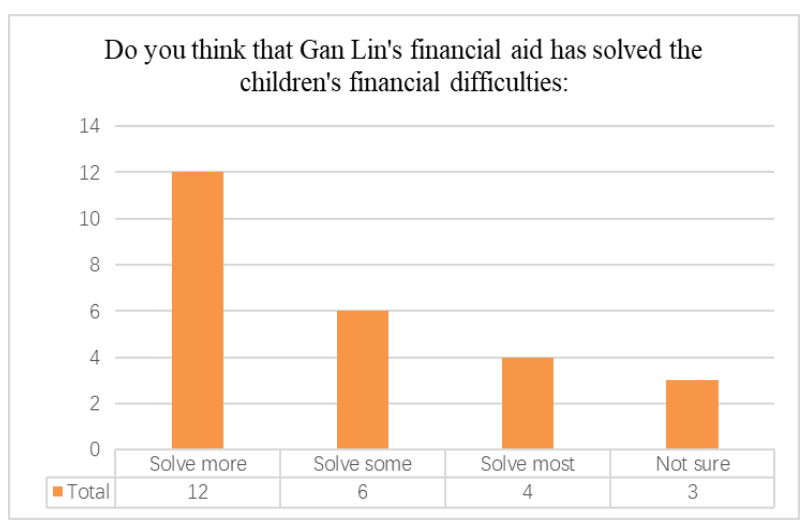

The survey results demonstrated that Ganin, a typical grassroots NGO in China has some positive influence on people. These students are all from low-income families in five different rural areas near Xuzhou. Nearly all of their families have disabled or ill family members. $31 \%$ of students have been helped over two years and $50 \%$ of them have been helped for one to two years. Figure 2 shows that all of them want to participate in charity work in the future, and 78\% among them show their strong will. Thanksa to Ganlin's help, they show great interest in studying and are eager for educational resources. 


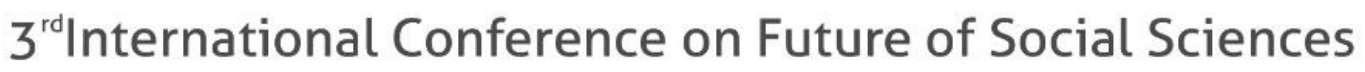

These two groups of data (Figure 3 and 4) show a direct contrast between what Ganlin has done and how their recipients have been influenced. $67 \%$ of the students think that Ganlin's donation helps them solve a few troubles. While half of the volunteers believe that the organization fund-raising helped a lot, only $30 \%$ of the students show agreement. This gap demonstrates that the donation is not as effective as volunteers believe. When asked about further thoughts nearly all volunteers state that children must think Ganlin's donations help their families solve a lot of financial problems. This might result from the expectancy bias which makes them feel good for their organization. However, they fail to collect students' feedback and evaluate the effect of their work accordingly.

According to Philip H.Brown and Albert Parks (2002), if children who have a better learning ability or more supportive parents choose to attend higher-quality schools, the measured effect of school quality variables will be biased upward. However, they found out from their sample (i.e. 300 children from low-income families) that the effect of school quality is relatively small. This result indicates that though families guarantee children's education, they do not have an awareness of a good-quality education. In this survey, the 104 children imply that they are lack of resources. 97\% of them need daily supplies and learning materials that are basic study resources. From Figure 5, we can see that only $30 \%$ of them want tutors to give them extra help on schoolwork. The lack of requirement does not mean that they have no need for tutors. Instead, they have no idea of what a tutor is like because there are no peer or adult tutors in that town.

Figure 5: Requirements for learning of Children Supported by Ganlin

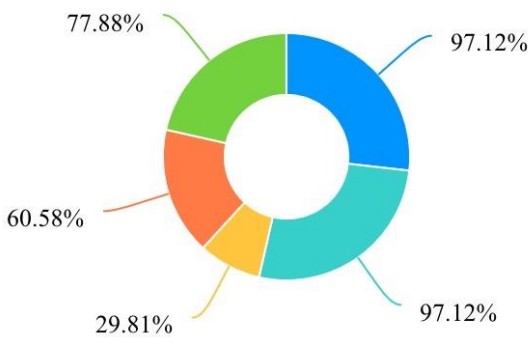

Daily school supplies (such as pens, notebooks, school bags, etc.)

Textbooks, supplementary materials, and extracurricular books

Teachers outside the classroom, tutors to tutor homework or expand knowleds

Opportunities for exchange ideas and learning with other children

Knowledge through the Internet (mobile phone, computer, etc.)

Based on the analysis from Chapter 4.2 and 4.3, we can conclude some main problems grassroots organizations are facing. Further, combined with data collected from the Internet, there are three main problems of grassroots NGOs in developing countries, discussed in details below:

First, grassroots NGOs in developing countries are lack of talents. Talents refer to people working as full-time staff for the organization in this research. According to the China Development Brief, the NGOs they interviewed are relatively small organizations. $44.8 \%$ of them have no more than three staff and $10 \%$ do not have any full-time staff. Also, the turnover rate of grassroots NGOs and club employees is about 60\% in 2011, much higher than in other careers. Ganlin is the most powerful local charity organization in the city, 


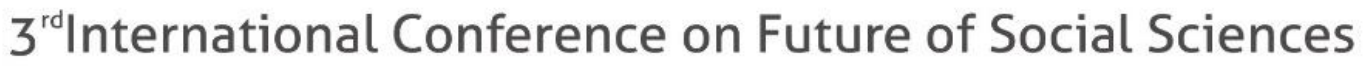

Xuzhou. However, it does not have any full-time staff. The founders paid an accountant 1000 CNY per month whose obligation only includes transferring money into the families' bank account. However, undergraduates in China may do voluntary work at school because experiences are important to them. Few of them would choose small-sized grassroots staff as a career because of the low payment, low-quality working conditions, and job instability. Lack of talents is a common and serious problem that limits the development of grassroots organizations.

Second, small-sized grassroots are lack of professionalism. Their core volunteers have little professional knowledge because few of them have studied or been trained before. For example, one of the founders in Ganlin once participated in a charity training in Beijing five years ago. Nevertheless, she has never had any opportunity to acquire knowledge about management or charity work since then. Most grassroots NGOs are founded by people who have devoted many years to doing voluntary work. They are into helping others but neglecting to manage the organization. Volunteers are short of Internet technology so that they are unable to post the donations or list activities through social media. Local small-sized NGOs need to focus on the structure of the organization, the training for the volunteers, and the platform of information spreading.

Third, small civil NGOs have low public participation. More specifically, they are influential because of their devotion, but only a small number of people know about Ganlin and donate to it. Many advertisements have been word of mouth, a traditional and high-quality method. The disadvantages are the low speed of information diffusion and the lack of motivation to raise money. As a result, expanding the scope of grassroots NGOs is difficult in modern society.

\section{Conclusion}

Small-sized grassroots nonprofit organizations play a prominent but little understood role in delivering public services. They must ultimately find their own way. Change must come from within, and be guided by a strong and clear vision of the role they believe they can play in the twenty-first century. Regarding the issues listed above, the study provides three key solutions:

To attract more talents, grassroots NGOs must allocate their resources reasonably. Because of China's traditional charity concept, the public generally does not approve of management funds and believes that the donated money should be directly used for the rescued person and cannot be used to pay for the charity organization employee's wages. Besides, according to the Bylaw of Foundation (2004), the total salary and welfare of the foundation's staff cannot exceed over $10 \%$ of total expenses. Sparing some of the donations into running the organization. Moreover, paying attention to young generations, grassroots NGOs can cooperate with schools and bring charity culture into them. Advertisement can be made by posters, leaflets, or passages on school's official social media. Also, volunteers in grassroots NGOs are able to contact the student organizations or clubs, giving charity lectures or seminars to let students be aware of the meaning behind the work. 


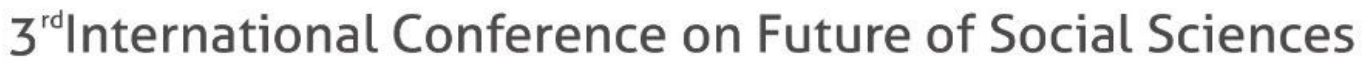

Second, there need to be professional training resources for volunteers. To begin with, local grassroots organizations should reach out to other charities or service organizations to share resources. For example, Ganlin is one of the members of Xuzhou Social Organization Cultivation Program built in 2020. They hold seminars to exchange experience and learn from each other. However, the league is loose and organizations do not build a close connection with each other. Moreover, there are plenty of online resources nowadays. Due to the development of MOOC platforms, there are free educational and professional lessons or lectures for volunteers. Founders should learn first and then assign learning tasks to their teammates. After studying, they can build a functioning system within their own organization. All people in charge may have meetings regularly to discuss their recent work and convey conclusions to volunteers.

Third, grassroots organizations should expand their impact and raise citizens social awareness through social media. The social accounts of TV stations and newspapers have main resources to reach out. Moreover, both of them have a social media account to report news too. The most important goal is introducing the organization itself by adding examples to support the effort it has made. Thus, people will have an overall view of grassroots NGOs, together with charity work. First of all, they need to establish what modern charity consciousness is. Modern philanthropy consciousness is not giving out of mercy and pity that is reflected in traditional Chinese philanthropy activities, but can be expressed as "equality, mutual assistance, fraternity, and sharing." Second, they can try to create a charity atmosphere using public service announcement or posting passages. Third, setting up examples contributes to appealing for participation. In this way, citizens may actively reach out to Ganlin and learn more about the children they are helping.

To sum up, grassroots NGOs in China contribute a lot to alleviating poverty, promoting social equality, and solving social conflicts. They provide help both finically and mentally to vulnerable groups. The Government can involve in all the three methods by building close connections with grassroots NGOs. Although most of NGOs are local and small-sized, they still have many opportunities to further develop themselves. Grassroots NGOs in developing countries must realize their problems in functioning and make changes according to the suggestions above.

\section{References}

Yang and Zhang, (2012). "The Research of Charity Organizations Current Situation and Further Development,”慈善组织发展状况和完善路径研究 Proceedings of Tianjin Social Science Annual Conference, Tianjin, China, pp.406-412.

Two Years After Lushan Earthquake, Clear Usage of Foundation's Fundraising, 芦山地震两 周年 基金会善款流向清晰. [online]. Available: http://zqb.cyol.com/html/2015-04/21/nw.D110000zgqnb_20150421_1-04.htm.

Lin, (2014). "Charity Fundraising Development Research in Contemporary China - and a Comparison with the United States," Graduate thesis, Modern and Contemporary History of China, Hunan Normal University, Hunan, China. 
The Development History of Non-governmental Organizations in China, 脉络最清楚的中国 NGO 研究发展史. [online]. Available: http://www.chinadevelopmentbrief.org.cn/news-18750.html.

Gao, (2010). “The Functioning Mechanism of American Charity Organizations,”美国慈善 捐赠的组织运行机制. Study and Practice, vol.4, pp.117-122.

Liu, (2010). "From Chinese Experience to Chinese Mode: the Logic of Culture, the Limitation of Experience, and the Orientation of Development," 从中国经验到中国模 式慈善救助之文化逻辑、经验局限与发展走向. Fujian Tribune The Humanities Social Sciences, vol.2, pp.156-161.

$\mathrm{Li}$, (2006). "Reflect the Transformation of Supporting China's Orphans in Rural Areas According to Western Children's Welfare Social Norms,”从西方儿童福利范式的演 变看我国农村孤儿救助制的转型. Academic Forum, vol.12, pp.69-71.

Yuan Yang, (September, 2019) “Annual Report on China’s Philanthropy Development (2018),” 2018 年度中国慈善捐助发展报告. Beijing: Social Sciences Academic Press, [Online]. Available:

http://www.charityalliance.org.cn/u/cms/www/201909/23083734i5wb.pdf

Park, Albert, and H. Brown, (2002). "Education and Poverty in Rural China," Economics of Education Review, vol.21, Issue 6, pp.523-541.

Shieh and Brown-Inz, (2013). "China’s NGO Brief: Special Report of China's Voluntary Organizations Directory, ”中国 NGO 概览—— 《中国公益组织名录》特别报告. China Development Brief.

Chen, (2014). “Grassroots Charity Organizations Supporting Parentless Children in Poverty:

A case study of HD county in H province,” 民间慈善组织参与孤贫儿童救助研究 - 以 $\mathrm{H}$ 省 HD 家园为例. Master Thesis, Jilin University, Jilin, China.

Li, (2014). “America's Public Charity Organization Marketing Offers China Suggestions,” 美国非营利支持组织发展及对中国的启示. Master Thesis, Nankai University, Tianjin, China.

Yang, (July, 2019). “Annual Report on China’s Philanthropy Development (2019),”2019 年 度中国慈善发展报告. Beijing: Social Sciences Academic Press.

Lewis, (2009). "Nongovernmental Organizations, Definition and History," International Encyclopedia of Civil Society, Ed. Helmt K.Anheier, Stefan Toepler, Regina List, pp.1056-1062.

Zhang, Xiaobo and Kanbur, (2005). Spatial Inequality in Education and Health Care in China, China Economic Review, vol.16, pp.189-204.

Statistical Communiqué on the Development of Civil Affairs (2018), 2018 年民政事业发展 统计公报. [online]. Available:

http://images3.mca.gov.cn/www2017/file/201908/1565920301578.pdf

Goldstein, (2007) "Cognitive Psychology: Connecting Mind, Research and Everyday Experience," Belmont: Wadsworth Publishing, p.374. 


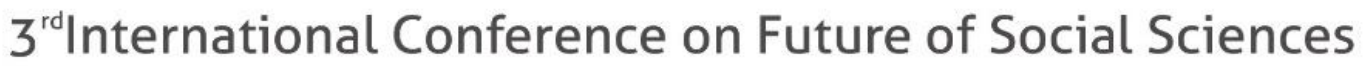

The Survey about Charity Staff's Salary: Work for Grassroots NGO for Three Years, Deposit not Over One Thousand，公益从业者薪资调查 草根 NGO 工作三年存款未上千. [online]. Available: http://www.chinadevelopmentbrief.org.cn/news-4215.html

Kirk, (July 2012). "Beyond Charity: Helping NGOs Lead a Transformative New Public Discourse on Global Poverty and Social Justice, Academics Stand Against Poverty," Cambridge University Press, vol. 26, Issue 2, pp.245-263.

Zheng, (2015). The Development of China's Charity Work and its Direction, Background, Awareness, Law, Organism, 中国慈善事业的发发展与需要努力的方向、背景、意识、 法制、机制. Academia Bimestris, vol. 2, p.3.

\section{Appendix}

\section{A. Survey to the Children Helped by Ganlin}

The target of the research is the children who are subsidized by Ganlin. The purpose of the survey is to learn about whether or not Ganlin's aid to students in difficulty is effective and to understand the current situation of children's lives in rural China. The result is only used for academic research. This research guarantees confidentiality and will not reveal your personal information! Please read carefully and answer the following questions. Thank you for your cooperation!

1. Your gender :

oMale

oFemale

2. How long does Ganlin help and care about you?

$\square$ Within half a year

$\square 0.5$-1year

$\square 1-2$ years

umore than 2 years

3. How many difficulties do Ganlin's donation help you solve :

oNone

$\circ$ A few

○Not sure

$\circ$ A lot

oMost

4. How much love and care do you feel from Ganlin :

$\square$ None

$\square$ Little

$\square$ General

$\square$ Some 


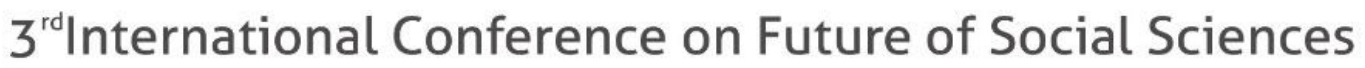

$\square$ Much

5. What activities in Ganlin did you join or participate : (Multiple choices )

$\circ$ Volunteers visit you

○Join "caring father \& mother" activities

oSpecial festival celebrations

$\circ$ Visit and learn in a city tour

oOthers :

6. After you finish your study and life, have the ability to work and make money, are you willing to participate in public welfare activities:

$\square$ Not willing

$\square$ Not very willing

$\square$ General

$\square$ More willing

$\square$ Very willing

7. Do you think your current learning resources are sufficient?

$\square$ Insufficient

$\square$ Relatively insufficient

口General

$\square$ Relatively sufficient

$\square$ Very sufficient

9. How many siblings do you have:

$\circ 0$

$\circ 1$

$\circ 2$

○3 or more

10. Whether your parents work in the field:

$\square$ Father works

$\square$ Mother works

$\square$ Parents both work

$\square$ Parents do not work

11. Whether the family has disability, illness, etc.:

o Grandparents have

$\circ$ Parents have

oBrothers and sisters have

oOthers:

12. What kind of help do you need for learning: (multiple choices)

$\square$ Daily school supplies (such as pens, notebooks, school bags, etc.)

$\square$ Textbooks, supplementary materials and extracurricular books

$\square$ Teachers outside the classroom, tutors to tutor homework or expand knowledge

$\square$ Opportunities for exchange ideas and learning with other children 


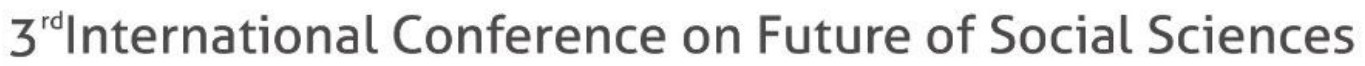

$\square$ Knowledge through the Internet (mobile phone, computer, etc.)

$\square$ Others:

B. Survey to core volunteers working for Ganlin

Hello! The target of this survey is people who donated money to the poor children through Gan Lin Educational Assistance Organization. The purpose of the survey is to understand the opinions and attitudes of the caring people towards the public welfare organizations, as well as their views on the public welfare. The final statistical results is used for academic research only. This survey guarantees confidentiality and will not require any private personal information. I hope you read it carefully and fill it in, thanks for your cooperation!

1. Your gender:

oMale

oFemale

2. How long have you been donating or caring for students in need in Ganlin:

$\square$ Within half a year

$\square$ Half a year to 1 year

$\square 1$ to 2 years

$\square 2$ to 3 years

$\square$ More than 3 years

3. Your monthly salary income (RMB):

○3000 or less

○3000-6000

$\circ 6000-9000$

○9000-12000

○ 12000 or more

4. On average, the money you donate to students in need through Gan Lin's student assistance:

$\square 200$ or less

$\square 200-400$

$\square 400-600$

$\square 600$ or more

$\square$ Only participate in everyday donation

5. You have docked several students:

$\circ 0$

$\circ 1$

$\circ 2$

○3 or more

6. What activities have you organized or participated in in Ganlin Student Aid: (multiple choices)

$\circ$ Visiting volunteers

o Caring parents

oSpecial festival event 


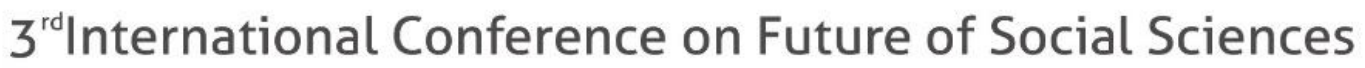

$\circ$ Visiting and learning activities in Xuzhou City

oOther:

7. Do you think that Gan Lin's financial aid has solved the children's financial difficulties:

oNo solution

oSolve some

oNot sure

oSolve more

oSolve most

8. Gan Lin's help in learning helps children feel the level of care:

$\square$ Almost nothing

口Less

$\square$ Generally

$\square$ More

$\square$ Many

9. Your age:

oUnder 20 years old

○20 to 30 years old

○30 to 40 years old

$\circ 40$ to 50 years old

$\circ 50$ years old and above

10. In your opinion, how rich are the educational resources of rural children funded by student aid organizations?

$\square$ Very insufficient

$\square$ Insufficient

$\square$ General

$\square$ Relatively sufficient

$\square$ Very sufficient

11. What do you think of the development of Chinese local NGOs:

oVery poor

oRelatively Poor

oGeneral

oRelatively good

oVery Good

12. What do you think are the problems of Chinese grassroots NGOs like Gan Lin:

口Lack of talent

$\square$ The legal system of public welfare organizations is not perfect (problems such as difficulties in fundraising)

$\square$ Open and opaque funds and poor social credibility

$\square$ Organization's own staff structure, rules and regulations are waiting to be improved $\square$ The propaganda is not strong and the public participation is low 


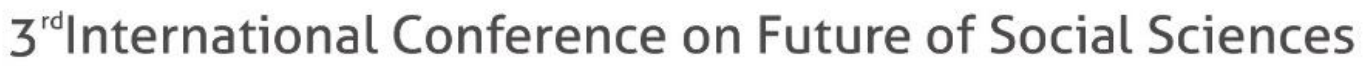

$\square$ Others:

13. Some research surveys point out that Chinese NGOs are "national strong and local weak." This statement means that powerful public welfare organizations, which are often "national prefix" organizations initiated or supervised by government departments, such as the Chinese Red Cross and China's poverty alleviation, Foundation, etc. However, with the increasing awareness of entrepreneurs and the public, many private charitable organizations have gradually expanded their influence. What do you think of this phenomenon?

14. Do you have any other suggestions about grassroots NGOs in China? 